Article

\title{
Impact of Non-Agricultural Employment and Environmental Awareness on Farmers' Willingness to Govern the Heavy Metal Pollution of Farmland: A Case Study of China
}

\author{
Hua Lu(1) \\ Institute of Ecological Civilization, Jiangxi University of Finance and Economics, Nanchang 330013, China; \\ luhuanj@126.com; Tel.: +86-158-7068-4035
}

Received: 27 February 2019; Accepted: 2 April 2019; Published: 8 April 2019

\begin{abstract}
Heavy metal pollution of farmland is a significant issue affecting the quality of agricultural products and human health. Farmers' behaviors can have a direct impact on the level of heavy metal pollution affecting farmland in China. Whether the heavy metal pollution of farmland can be effectively governed at a low cost depends on the farmers. This paper analyzes the mechanism by which the extent of non-agricultural employment and environmental awareness influences farmers' willingness to govern the heavy metal pollution of farmland using microdata for farmers in China and conducts an empirical analysis via a logit model. The results show that farmers in China display low willingness to govern the heavy metal pollution of farmland and that the increase in non-agricultural income will not significantly improve this willingness. Environmental awareness and farmers' willingness to govern the heavy metal pollution of farmland are closely related: the higher the environmental awareness of farmers is, the stronger their willingness to govern heavy metal pollution, and the higher the probability of their participating in fallow land treatment. The government can introduce incentives to improve farmers' environmental awareness of the heavy metal pollution of farmland. In addition, the government should strengthen publicity about the positive effects of fallow land treatment and encourage farmers to participate in the governance of heavy metal pollution of farmland. Given increasing non-agricultural employment opportunities and the transformation of agricultural production modes, agricultural technical training provided by governmental departments can enable them to be more scientific and rational in their agrochemical selection and application, thus reducing or avoiding the heavy metal pollution of farmland at the source. Attention should be paid to the differences between farmers to ultimately reduce the cost and improve the efficiency of treatment.
\end{abstract}

Keywords: heavy metal-polluted farmland; environmental awareness; non-agricultural employment; fallow policy; willingness; China

\section{Introduction}

Environmental issues attributed to human activities are becoming increasingly visible. Heavy metal pollution of farmland (HMPF) is a serious issue in China that urgently requires treatment [1-3]. The characteristics of HMPF are potentially invisible and long-term [4,5]. Heavy metals accumulate easily in natural environments, are not easy to leach with water and are not easily degraded by microorganisms [6]. After they accumulate in soil, heavy metals will accumulate in plants, animals and human bodies as they progress through the food chain, thereby posing a serious threat to the ecological environment, food safety and human health and directly affecting the sustainable development of the social economy. According to the "National Soil Pollution Investigation Bulletin" issued by the 
Ministry of Ecology and Environment of China, the total overstandard rate for soil in China is $16.1 \%$, of which $11.2 \%, 2.3 \%, 1.5 \%$ and $1.1 \%$ represent slightly, mildly, moderately and severely polluted soil, respectively [7]. HMPF is more extensive in the south than in the north of China and the overstandard rate of cultivated land pollution in China is $19.4 \%$ [7]. As of 2014, among the 92.4 million hectares of cultivated land surveyed, 5.266 million hectares were lightly polluted by heavy metals and 2.325 million hectares were moderately or severely polluted, accounting for $8.22 \%$ of the investigated cultivated area [8].

Governing HMPF and reducing its harm has become a major problem that urgently needs to be solved and it is the key to realizing the sustainable use of cultivated land resources and to the environmentally friendly development of China. In many countries or regions, fallow land is an important means of recuperating polluted farmland [9-11]. In June 2016, the Chinese government issued the "Pilot Program for Exploring the Implementation of the Farmland Rotation Fallow System," proposing a focus on fallow land in an area experiencing heavy metal pollution in Hunan Province. The plan stipulates that it is strictly forbidden to plant edible agricultural products during the fallow period; instead, farmers should plant crops with high biomass and cumulative absorbing effects. The plan also stipulates that those who are identified as the main polluters must fulfill the obligation of repair and treatment, with the government providing funds for repair and subsidies for leaving the land fallow. Leaving land fallow combined with targeted control measures can improve soil $\mathrm{pH}$ and adsorption, reduce the pollution of cultivated land and promote the sustainable production capacity of land [12]. In October 2017, the report of the 19th National Congress of China reemphasized the need to "strengthen the control and restoration of soil pollution and expand the fallow land trial" [13].

As the subject of agricultural production and management, farmers can have a direct impact on HMPF by applying fertilizer and pesticide, plant selection, fallow land management or technology application. The active participation of farmers can effectively reduce moral hazard and improve governance efficiency. Whether farmers are willing to participate in the treatment of HMPF depends on agricultural input costs, future farmland benefits, household characteristics and their risk awareness to farmland heavy metal pollution. On the one hand, non-agricultural wages are rising and the number of farmers engaged in non-agricultural employment is gradually increasing. Especially in the hilly and mountainous areas in China, there is a large number of younger laborers engaging in non-agricultural employment and agricultural aging and part-time employment among farmers are widespread. The large-scale transfer of younger laborers has led to a reduction in the effective labor supply in agriculture and insufficient investment in the treatment of HMPF [14]. In addition, the increase in household non-agricultural income alleviates the financial constraints in agricultural production. On the other hand, non-agricultural employment can broaden farmers' access to information, promote the development of rural labor capacity and improve farmers' environmental awareness of HMPF. People have focused more on the economic value of farmland and have neglected ecological and social values for a long time in China. The lack of social awareness around farmland protection in China has led to a low awareness of environmental protection among farmers [15]. The hidden and potential characteristics of HMPF make it difficult for farmers to generate the enthusiasm and initiative needed to control pollution. However, China's ecological environment constraints are becoming tighter and the public's demand for the safety of agricultural products is also increasing. These phenomena cannot be ignored and exploring the mechanism influencing non-agricultural employment and environmental awareness and its effects on farmers' willingness to govern HMPF is of great significance if the government is to prepare corresponding policies to construct an agroecological civilization.

Farmers are the main users of farmland, under the background of accelerating agricultural large-scale operation, agricultural production methods and the livelihood structure of farmers have undergone great changes in China. It is important to understand how to mobilize the enthusiasm of farmers and improve the implementation efficiency of heavy metal pollution control in farmland to promote the effective management of HMPF. The main contributions of this paper are as follows: This paper incorporated the farmers' non-agricultural employment, environmental awareness and 
their willingness to govern HMPF into an analytical framework and an econometric model was used to analyze these effects based on the improvement of farmers' environmental awareness ability, especially in the context of tightening environmental constraints and the increasing public demand for high-quality agricultural products.

\section{Literature Review}

HMPF is a subject attracting wide concern from scholars in China and abroad, due to its universality, management challenges and ability to cause harm. A number of studies have focused on the heavy metal content of arable soil [16], source analysis [17], pollution assessment [18-20], ecology [21] and health risk evaluation [22]. Heavy metal pollution control research taking the perspective of farmers is minimal and there is even less empirical analysis. Most of the research on China has focused more on cultivated land protection and the adoption of environmentally friendly agricultural technology [23-28]. Age, sex and agricultural laborers are the main factors that influence farmers' willingness to invest in organic fertilizer, water conservancy construction and soil improvement [26]. Yang et al. compared the differences in the input behavior of cultivated land protection across different types of farmers taking a part-time employment perspective and found that part-time employment has a significant negative impact on farmers' cultivated land protection and decreases with increasing part-time employment. The first part-time job taken only has a significant negative impact on capital-biased investment, while a second part-time job only has a significant negative impact on labor-biased investment [28]. Experience of migrant workers would also promote the ability to develop a rural labor force, improve the ability to acquire new technologies and increase the probability of adopting sustainable agricultural technology [29]. Non-agricultural employment leads to a reduction in the effective agricultural labor supply, which will deepen agricultural nonpoint source pollution [14]. The non-agricultural labor supply also significantly reduces the probability of farmers adopting sustainable agricultural technology [30]. Scholars have also analyzed cultivated land protection considering intergenerational differences [31], land sentiment [32] and the natural attributes of cultivated land [33,34]. Many scholars also believe that the stability of farmland management rights will affect farmers' expectations for land use and farmland investment and thus have a significant impact on long-term agricultural investment, including green manure, the application of organic fertilizer and straw incorporation [35-42].

Research on the treatment of HMPF has mainly focused on nature science or macroscopic scales such as the path of treatment technology, treatment approaches and the influence of specific technologies on cultivated land restoration and crop quality [43-45]. For example, GIS has been used to assess heavy metal concentrations and their spatial variations [44] and a novel assessment method of heavy metal pollution based on reactive heavy metals has also been employed [45]. Moreover, the effects of the use of treated municipal sewage and the use of subsurface drip irrigation on the accumulation of heavy metals and health of the soil and grains using a health risk index have been explored [46]. The soil load capacity control method is thought to be an effective measure to control heavy metal pollution [1]. Some papers have reviewed the research progress of heavy metal-contaminated land remediation technologies (including physical remediation, chemical remediation, bioremediation, agroecology and joint remediation) in China and abroad [47-50]. Fan et al. showed that joint remediation can somewhat overcome the shortcomings of a single repair method, improve the repair effect and reduce the repair cost [47]. The Nemerow pollution index, EPA human exposure risk assessment and potential ecological hazard index methods have also been used to evaluate the potential health risks of HMPF related to agricultural products [51].

With the increasingly rapid transformation of traditional agriculture to modern intensive agriculture, agricultural production has become one of the major factors affecting HMPF. Recently, a few scholars have begun to analyze the treatment of HMPF from the perspective of farmers in China using social science methods [52-54]. As the basic economic unit of agricultural production, rural households play a crucial role in this process and it is widely known that some types of agricultural 
production promotes HMPF $[55,56]$. Rural households' land utilization mode affects the heavy metal content in soil, for example, the degree of heavy metal pollution in soil for intensive planting is higher than that of traditional planting [52]. Rural households' environmental awareness level is an important factor affecting their behavior and thus, the emergence and aggravation of HMPF are largely related to the low environmental awareness level of these households [53,54]. In addition, some paper compared farmers' preferences for compensation schemes for heavy metal pollution in China $[57,58]$. Yu et al. argued that paying attention to publicity and training around farmers' use of fallow land can improve farmers' input in the treatment of HMPF and their awareness of ecological value, which is conducive to improving their fallow land [57]. The main driving force behind farmers adopting technology to rehabilitate heavy metal pollution in farmland comes from the government; family characteristics have no significant effect on the adoption of rehabilitation technologies [3]. Moreover, Li et al. proposed that farmers' environmental awareness of heavy metal pollution products can be improved by policy incentives that guide the application of remediation technology.

Previous research has provided the research basis for this paper but further research is needed. The pollution control of heavy metals in farmland needs not only the promotion of government policies but also the active participation of farmers. Improving farmers' environmental awareness and actively accepting an environmental policy are the most fundamental ways to reduce implementation costs and prevent moral hazard in China. Most of the existing research has focused on macroscale perspectives [43-45] and qualitative or quantitative studies on the microscale perspective of farmers are still relatively scarce. These studies have ignored the positive effect from improving farmers' environmental cognitive ability on the treatment of HMPF. Research on the relationship between farmers' environmental awareness and the heavy metal pollution control of China's farmland is insufficient.

\section{Analytical Framework}

As rational economic actors, farmers will choose the optimal resource allocation or behavior mode to maximize their utility based on limited resources and institutional constraints. Whether farmers are willing to participate in the treatment of HMPF depends on agricultural input costs, the future benefits to farmland, household characteristics and their awareness of the dangers of heavy metal pollution of farmland.

First, the rapid development of China's economy promotes the transfer of agricultural labor to non-agricultural sectors and the proportion of non-agricultural income to total household income continues to increase, alleviating capital mobility constraints and helping lift farmers' disposable income. In addition, with the deepening of rural reform and the confirmation of farmland rights in China, farmers' awareness of farmland property rights and expectations for rural land appreciation are becoming stronger and their enthusiasm for land preservation is growing. Therefore, to increase yields from farmland, farmers' willingness to govern HMPF will be strengthened with higher non-agricultural benefits.

Second, non-agricultural employment leads to a decrease in the effective agricultural labor supply and a strengthening of labor constraints in the treatment of HMPF. The aging of agricultural production, the increase in part-time employment among farmers and the increase in non-agricultural wages are also having serious effects and the agricultural cost to manage a small area of land is increasing for each household. It is also difficult for farmers to transfer to the land adjacent to their contracted plots through one-time transfers because of the restriction on terrain and the slow development of the land transfer market. In addition, the transfer cost is high and machinery cannot effectively replace labor in the hilly and mountainous areas of China. These issues reduce the enthusiasm with which farmers manage agriculture and their dependence on land, increase the possibility of land abandonment or extensive operation and reduce the willingness to govern HMPF.

Finally, non-agricultural employment can improve farmers' environmental awareness by broadening access to some information channels. Farmers are the direct beneficiaries of the treatment 
of HMPF and their environmental awareness affects their willingness to control HMPF. Behavioral attitudes, subjective criteria and perceptible behavior can jointly determine behavioral motivation and behavioral attitudes have an important impact on behavioral motivation [59]. If farmers believe that HMPF affects their own or their family's health, damages the ecological environment or experience enhanced awareness of environmental protection, then their willingness to participate in the treatment of HMPF will increase with increased non-agricultural employment.

Non-agricultural employment and environmental awareness will affect farmers' willingness to govern HMPF (Figure 1). However, the influences of these action paths differ. The strength of each action path ultimately determines the direction and degree of farmers' willingness to control HMPF.

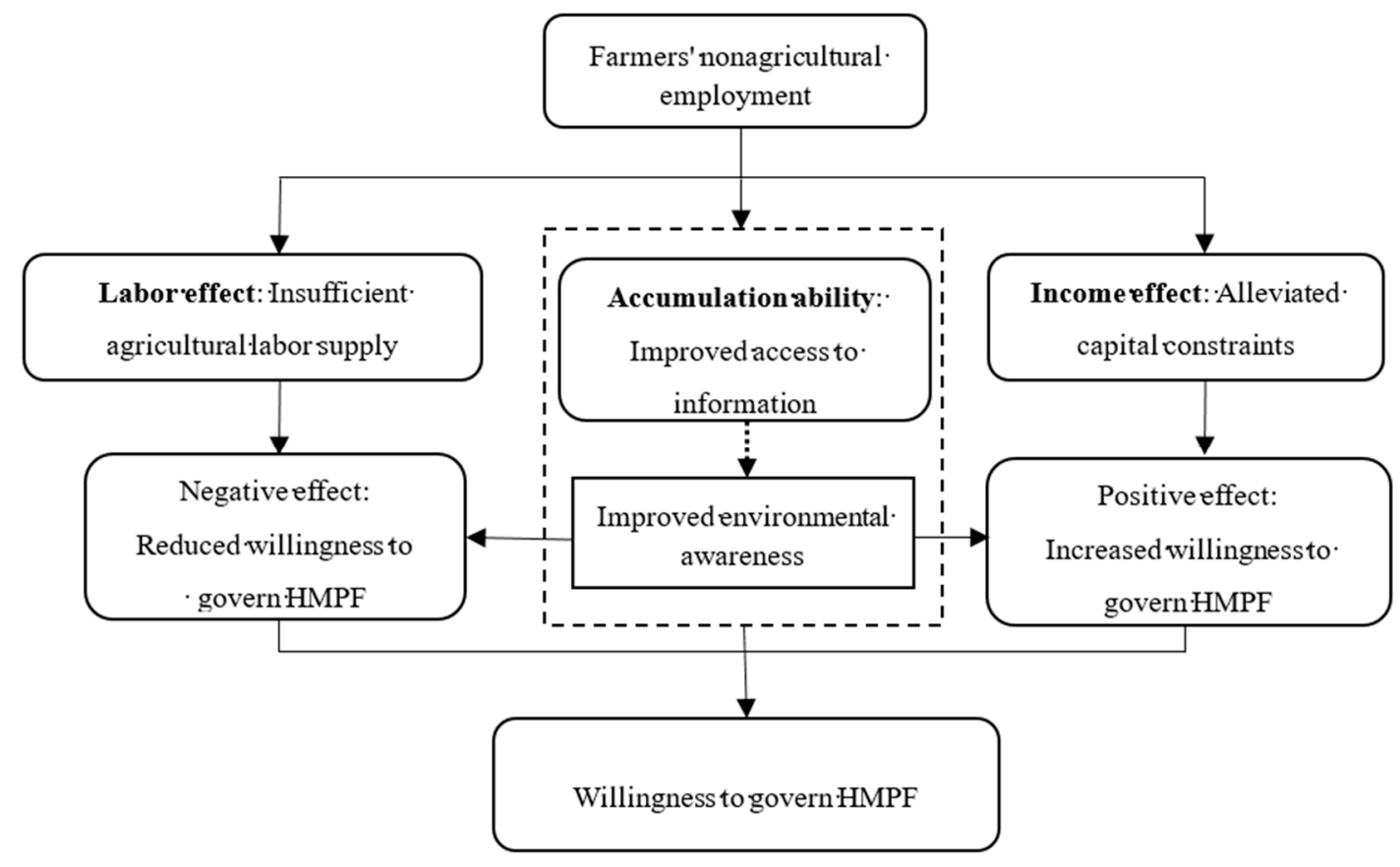

Figure 1. Analytical Framework.

\section{Farmers' Awareness of HMPF}

\subsection{Data Source}

Jiangxi and Hunan Provinces have long been the major grain-producing areas in China. Hunan Province is located along the middle reaches of the Yangtze River in central China. The soil is dominated by red soil, followed by paddy soil and fluvo-aquic soil; the latter two are the main agricultural soils. The farmland area was $4.15 \times 10^{4} \mathrm{~km}^{2}$ in 2014 in Hunan Province. It is known as the "hometown of nonferrous metals" and nonferrous metal mining has led to heavy metal pollution of up to $28 \times 10^{4} \mathrm{~km}^{2}$, which means that $13 \%$ of the total land area is polluted by heavy metals in Hunan Province. In April 2014, Hunan province launched a pilot project to restore HMPF in cities of Changsha, Zhuzhou and Xiangtan, as the only national pilot approved by the Ministry of Agriculture and Rural Affairs of PRC (People's Republic of China) and the Ministry of Finance of PRC. Jiangxi Province is located in southeastern China and it is an important contributor of Yangtze River in central China. The total area of cultivated land in the province is $3.08 \times 10^{4} \mathrm{~km}^{2}$, accounting for $18.48 \%$ of the total land area. Being one of the top 10 producers of nonferrous metals in China, Jiangxi Province suffers from industrial and agricultural waste. According to the survey, with a moderate pollution level of $5.26 \%$, the heavy metal pollution of paddy soil in Jiangxi Province is the most serious in the central region [60]. Heavy metal pollution control in Jiangxi Province started even before the pilot study. Hunan Province and Jiangxi Province in China are the key provinces with respect to the prevention and control of heavy metal pollution (Figure 2). The heavy metal pollution areas of Changsha county, Chaling county 
and Xiangtan county in Hunan Province are national pilot areas for fallow land treatment. Leping county, Dexing county and Guixi county in Jiangxi Province are severely polluted by heavy metals. Therefore, these regions have important reference value for the treatment of HMPF in China, based on the diagnoses of samples from these provinces.

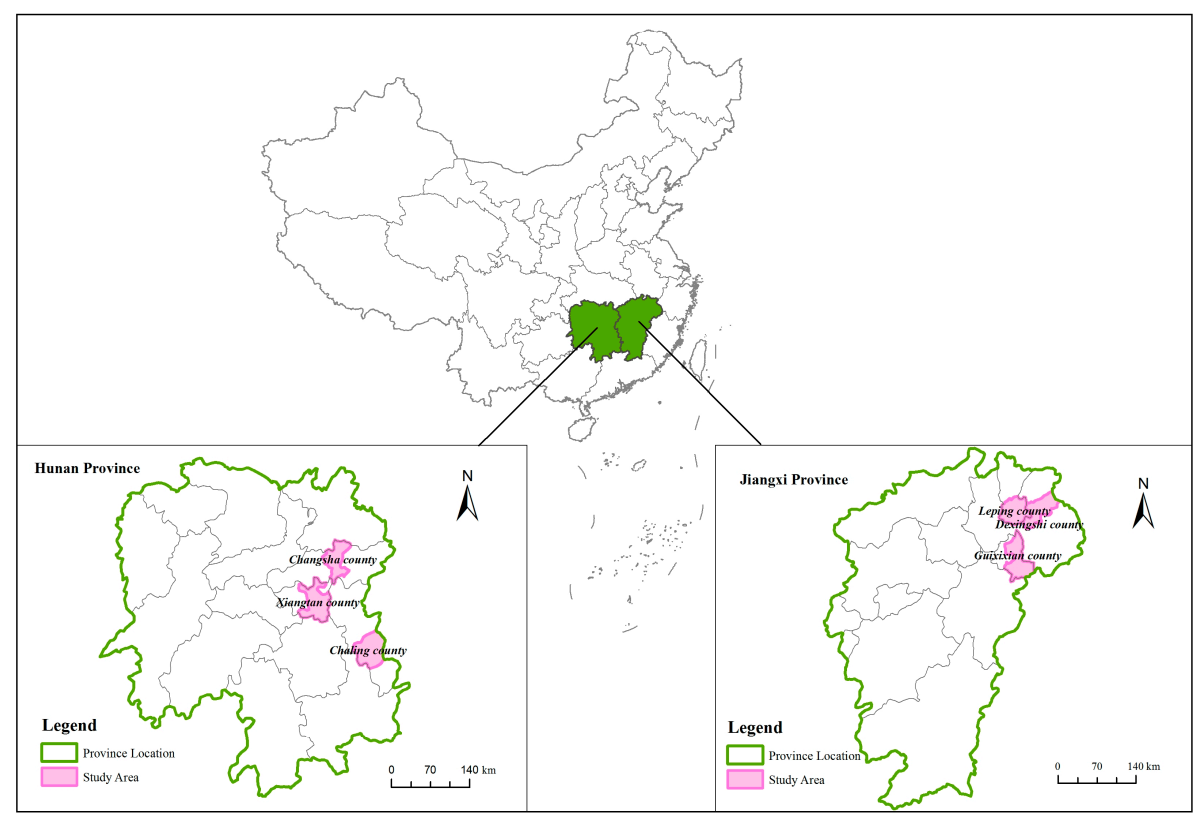

Figure 2. Location of Jiangxi and Hunan Province in China and the Study Area.

All of the data used in this study were collected through questionnaires provided to households in the Jiangxi and Hunan Provinces in 2016. To ensure the representativeness of the overall region, considering the differences among cultivated land areas in different towns of these regions in particular, we selected two towns from each county, then two villages from each town by the random sampling method. (Stratified random sampling is one of the random sampling methods. For example: Changsha County in Hunan province has a total of 13 towns, which are sorted into 2 groups according to the area of cultivated land. Then, one town is randomly selected from the 2 groups. In the same way, villages belonging to each town were divided into two groups, then one village was randomly selected from each group). The number of towns in Changsha county, Chaling county and Xiangtan county of Hunan province was $13,16,15$, respectively. The number of towns in Leping county, Dexing county and Guixi county of Jiangxi province was 16, 11, 18, respectively. The following aspects were included in the questionnaire: (1) household characteristics, such as age, education, the number of family laborers and household income; (2) the basic characteristics of the farmland, such as the agricultural acreage, abandoned area and its causes, fallow area and agricultural inputs and outputs; (3) the understanding of HMPF and participation in pollution control, including whether the farmers are willing to pay for treating the HMPF, recognizing the greatest impacts of HMPF, understanding the impact of heavy metal pollution on health and feeling responsibility for heavy metal pollution control; and (4) participation in the fallow land project, such as their understanding of fallow land and their satisfaction with compensation for leaving land fallow. To ensure the quality of the questionnaire, the content was revised several times following a pre-investigation. The formal investigation was conducted through face-to-face interviews between the investigator and the farmer. The investigators were composed of postgraduate and doctoral students from Jiangxi University of Finance and Economics and the investigators completed the questionnaires on behalf of the respondents. A Total of 274 questionnaires were distributed; 162 in Jiangxi province and 112 in Hunan province. The number of questionnaires in Leping county, Dexing county and Guixi county in Jiangxi Province were 58, 54 and 60, respectively. The number of questionnaires in Changsha county, Chaling county and Xiangtan county were 40, 35 
and 37, respectively. After the survey, 265 valid questionnaires were obtained by centralized testing and the effective rate was $96.83 \%$.

\subsection{Farmers' Awareness of HMPF}

The effects of HMPF are potentially invisible and long-term, which creates human health risks and deteriorates the ecological environment. Some farmers believe that HMPF has affected them or their families (Table 1). Agricultural production is an organic combination of natural and social reproduction. Heavy metal elements are absorbed by crops as they progress through the food chain, leading to the heavy metal pollution of agricultural products and affecting human health. Farmers generally believe that their cultivated land is moderately polluted by heavy metals and they have a strong awareness of heavy metal pollution in local cultivated land. The perception of the dangers of HMPF is generally high in the sample area, which has a positive effect on motivating farmers to control HMPF.

Table 1. Perceptions and attitudes of farmers about heavy metal pollution of farmland (HMPF).

\begin{tabular}{|c|c|c|c|}
\hline Option & Assignment & Mean Value & Std. Dev. \\
\hline $\begin{array}{l}\text { Has HMPF affected your health or } \\
\text { your family? }\end{array}$ & $\begin{array}{c}1=\text { no; } 2=\text { the impact is not } \\
\text { serious; } 3=\text { the impact is serious } \\
1=\text { no; } 2 \text { = lightly polluted; }\end{array}$ & 1.88 & 0.73 \\
\hline Is HMPF serious in your farmland? & $\begin{array}{c}3 \text { = moderately polluted } \\
4 \text { = severely polluted }\end{array}$ & 2.55 & 0.58 \\
\hline $\begin{array}{l}\text { Do you think heavy metal pollution } \\
\text { in local cultivated land is serious? }\end{array}$ & $1=$ no $; 2=$ mild $; 3=$ serious & 2.38 & 0.62 \\
\hline Number of observations & 265 & & \\
\hline
\end{tabular}

Note: The author calculated values based on the survey data.

Farmers are the ultimate behavioral subject of agricultural land use and agricultural production behavior of farmers is directly related to HMPF. The improper application of fertilizers, pesticides and sewage irrigation will lead to the accumulation of heavy metals in farmland. Farmers believe that the largest impact of HMPF is manifested in the reduction in crops, followed by affecting health, destroying the environment and reducing income (Table 2). More than half of the farmers believe that government departments are mainly responsible for HMPF, followed by pollution-emitting enterprises. Additionally, most farmers believe that the government should compensate farmers for any losses caused by HMPF and provide technical treatment for polluted cultivated land. Farmers in the sample areas of China do not have a strong awareness of the heavy metal pollution caused by their agricultural production behaviors and lack the initiative to control heavy metal pollution.

Table 2. Environmental awareness of farmers about HMPF.

\begin{tabular}{cccc}
\hline Option & Assignment & Mean Value & Std. Dev \\
\hline & $0=$ no; 1 = reduces crops & 0.59 & 0.49 \\
What do you think is the & $0=$ no; $1=$ damages the environment & 0.45 & 0.50 \\
largest impact of HMPF? & $0=$ no; 1 = affects health & 0.52 & 0.50 \\
& $0=$ no; $1=$ reduces income & 0.44 & 0.49 \\
Who do you think holds the & $0=$ no; $1=$ pollution-emitting & 0.46 & 0.49 \\
main responsibility for & enterprises & 0.51 & 0.50 \\
HMPF? & $0=$ no; $1=$ government departments & 0.23 & 0.42 \\
What do you think the & $0=$ no; $1=$ compensate losses & 0.67 & 0.47 \\
government needs to do to & $0=$ no; $1=$ punish sewage companies & 0.38 & 0.48 \\
govern HMPF? & $0=$ no; 1 = manage cultivated land & 0.70 & 0.46 \\
Number of observations & $0=$ no; $1=$ eliminate farming & 0.02 & 0.15
\end{tabular}

Note: (1) The authors calculated the values based on the survey data. (2) For each survey question, the farmer could choose multiple choices; thus, the values in each option may not add up to 1 . 


\section{Empirical Analysis}

\subsection{Models and Descriptive Statistics}

Whether farmers are willing to govern HMPF or participate in fallow land treatment is a typical discrete multivariate selection variable and is thus difficult to express with continuous numerical values. In addition, most of the environmental cognitive variables are not continuous values. The sorted data will be treated as a base and result in biased or inconsistent results if OLS is used for estimation. A logit or probit model suitable for the analysis of discrete dependent variables should be adopted. The probit model places more emphasis on the continuity of the standard normal distribution, reflecting the intensity of the selection. The logit model is a cumulative distribution function and does not require the use of continuous variables. Many discrete variables are used in this paper and it is therefore more appropriate to use the logit model for estimation $[3,61]$.

Therefore, this paper uses a logit model as the analytical model. The form is as follows:

$$
P_{i}=F\left(\phi+\sum_{j=1}^{m} \varphi_{j} X_{i j}+\mu\right)=\frac{1}{1+\exp \left(-\left(\phi+\sum_{j=1}^{m} \varphi_{j} X_{i j}+\mu\right)\right)}
$$

Further, by finding the logarithm of (1), we obtain:

$$
\ln \left(\frac{P_{i}}{1-P_{i}}\right)=\phi+\varphi_{1} X_{i 1}+\varphi_{2} X_{i 2}+\ldots+\varphi_{m} X_{i m}
$$

$\frac{P_{i}}{1-P_{i}}$ is the ratio of the probability of something happening to the probability of something not happening. In this context, it is the ratio of farmers' willingness to govern HMPF over their reluctance. $P_{i}$ indicates the probability that farmers are willing to govern heavy metal pollution or participate in fallow land treatment; $X_{m}$ represents the independent variables and corresponds to the explanatory variables that affect farmers' willingness to govern HMPF or participate in fallow land treatment; $\varphi_{m}$ is the regression coefficient; and $i$ indicates the selected sample.

The regression coefficient of the logit model cannot reflect the true extent of the influence of each variable on the dependent variable; it can be used only as the basis for comparing and ordering all the variables. The direction and degree of the influence of each variable on the dependent variable should be calculated quantitatively. To calculate and compare the influence degree of each variable, the variables must be analyzed through elasticity calculated using the constant logarithmic mode, that is, calculating the marginal contribution of the independent variable to the dependent variable. The marginal contribution refers to the impact of a one-unit change on the dependent variable when other variables are averaged. That is, the regression coefficients of the independent variables are explained by the odds ratio, which is as follows:

$$
\operatorname{odds}(p)=\phi+\varphi_{1} X_{i 1}+\varphi_{2} X_{i 2}+\ldots+\varphi_{m} X_{i m}
$$

Table 3 shows the descriptive statistics for the variables. Approximately $40 \%$ of the farmers in the sample area are willing to pay for HMPF and approximately 55\% are willing to participate in fallow land treatment. Compensation for leaving land fallow land can offset the agricultural losses it causes. Control of HMPF by farmers alone will not only increase the cost of agriculture but also possibly cause agricultural losses. The proportion of farmers' non-agricultural income is relatively high. Farmers in hilly and mountainous areas in particular have a low agricultural income. In addition, Jiangxi Province and Hunan Province are both major agricultural labor transfer provinces. The young labor force within a family often goes out to engage in non-agricultural work; feeding oneself becomes the priority of agricultural production and the main source of household income is not agricultural. As the results show, most farmers engaged in agricultural production are over 45 years old, their education 
level is generally lower than high school, the number in each family engaged in the agricultural labor force is only 2 and the purpose of grain production is mainly to feed the family. The average farm size in the sample is 0.26 hectares, which is below the national average [62] and the average farm size of Jiangxi and Hunan province was 0.27 ha and 0.24 ha in 2016, respectively [63,64]. Land fragmentation is very serious in Jiangxi Province and Hunan Province and the topography also leads to high transaction costs for agricultural land transfer and the inability of machinery to effectively replace labor. Given the background of increasing non-agricultural employment opportunities and rising non-agricultural wages, there is an increasing incentive for the agricultural labor force to instead go out for non-agricultural work. The phenomenon of farmland abandonment in Jiangxi Province and Hunan Province seems to be spreading.

Table 3. Descriptive statistics of variables.

\begin{tabular}{|c|c|c|c|}
\hline Variables & Assignment & Mean Value & Std. Dev \\
\hline $\begin{array}{l}\text { Willingness to pay for the } \\
\text { treatment of HMPF }\end{array}$ & $0=$ no; $1=$ yes & 0.40 & 0.49 \\
\hline $\begin{array}{l}\text { Willingness to participate in } \\
\text { fallow land treatment }\end{array}$ & $0=$ no; $1=$ yes & 0.55 & 0.50 \\
\hline Non-agricultural income ratio & $\begin{array}{c}\% \text { of non-agricultural income in } \\
\text { total income }\end{array}$ & 0.89 & 0.17 \\
\hline Age of head of the household & $\begin{array}{c}1=\text { under } 18 \text { years old } ; 2=18-28 \\
\text { years old; } 3=29-44 \text { years old; } \\
4=45-59 \text { years old; } 5=\text { over } \\
60 \text { years old }\end{array}$ & 4.35 & 3.03 \\
\hline $\begin{array}{l}\text { Education of head of the } \\
\text { household }\end{array}$ & $\begin{array}{c}1=0 ; 2=\text { primary school; } \\
3=\text { junior high school; } 4=\text { high } \\
\text { school; } 5=\text { university and above }\end{array}$ & 2.53 & 0.93 \\
\hline Sex of the head of the household & $1=$ male $2=$ female & 1.39 & 0.50 \\
\hline Household population & people & 8.57 & 2.27 \\
\hline Number of agricultural laborers & people & 2.06 & 1.10 \\
\hline Agricultural acreage & ha & 0.26 & 0.15 \\
\hline $\begin{array}{l}\text { Purpose of agricultural } \\
\text { production }\end{array}$ & $\begin{array}{c}1=\text { used for food; } 2=\text { part for } \\
\text { sale; } 3=\text { for sale at market }\end{array}$ & 1.74 & 0.63 \\
\hline $\begin{array}{l}\text { Is HMPF serious in your } \\
\text { farmland? }\end{array}$ & $\begin{array}{c}1 \text { = no; } 2 \text { = lightly polluted } \\
3 \text { = moderately polluted; } \\
4 \text { = severely polluted }\end{array}$ & 2.55 & 0.58 \\
\hline $\begin{array}{l}\text { Has HMPF affected your health } \\
\text { or your family? }\end{array}$ & $\begin{array}{c}1=\text { no; } 2=\text { the impact is not } \\
\text { serious; } 3=\text { the impact is serious }\end{array}$ & 1.88 & 0.73 \\
\hline $\begin{array}{l}\text { Does HMPF have the greatest } \\
\text { impact on the environment? }\end{array}$ & $0=$ no; $1=$ yes & 0.45 & 0.50 \\
\hline $\begin{array}{l}\text { Does the government offer } \\
\text { technical treatment of HMPF? }\end{array}$ & $0=$ no; $1=$ yes & 0.70 & 0.46 \\
\hline $\begin{array}{l}\text { Are you willing to give up } \\
\text { farming due to HMPF? }\end{array}$ & $0=$ no; $1=$ yes & 0.54 & 0.50 \\
\hline Understanding of fallow land & $\begin{array}{c}1=\text { do not understand; } \\
2=\text { understand a little; } \\
3=\text { understand }\end{array}$ & 1.53 & 0.56 \\
\hline $\begin{array}{l}\text { Attitude of village cadres } \\
\text { towards fallow land }\end{array}$ & $\begin{array}{c}1=\text { negative } ;=\text { do not care } \\
3=\text { general } ; 4=\text { active }\end{array}$ & 2.93 & 1.05 \\
\hline $\begin{array}{c}\text { Can fallow land repair restore } \\
\text { HMPF? }\end{array}$ & $1=$ no $; 2=$ uncertain $3=$ yes & 2.32 & 0.72 \\
\hline $\begin{array}{c}\text { Satisfaction with fallow } \\
\text { subsidies }\end{array}$ & $\begin{array}{c}1=\text { dissatisfied } ; 2=\text { neutral } \\
3=\text { satisfied }\end{array}$ & 1.34 & 0.66 \\
\hline Number of observations & 265 & & \\
\hline
\end{tabular}


Most farmers generally believe that cultivated land has been moderately polluted by heavy metals and that HMPF has at least partially affected their health or the health of their families; most farmers are also willing to abandon farming to address HMPF in China. Approximately half of the farmers believe that HMPF will have an impact on the ecological environment and the vast majority of farmers believe that the government should assume the primary responsibility for addressing HMPF. At the same time, farmers do not know much about fallow projects in China and it is generally believed that village cadres do not have a positive attitude toward fallow land, which leads to an insufficient understanding of the differences between fallow and abandoned land. Farmers are skeptical that fallow land can alleviate HMPF and satisfaction with farmland fallow subsidies is at a neutral level.

\subsection{Results Analysis}

Stata13.0 (StataCrop LLC, College Station, TX, USA) software was used for logit regression. To control for heteroscedasticity, autocorrelation and the possible influence of outliers, robust estimation was used for the regression. The following four models were established in this study, Model 1 and 2 are used to analyze the farmers' willingness to pay for the treatment of HMPF, while models 3 and 4 are used to analyze the farmers' willingness to participate in fallow land treatment. Moreover, models 1 and 3 are the results of farmers' willingness to pay for HMPF treatment and their willingness to participate in fallow land treatment without considering their environmental awareness, while model 2 and 4 are the regression results when controlling their environmental awareness. The Wald test is significant at the $1 \%$ level. The fit results of the four models are good and have strong explanatory power. The specific regression results are shown in Table 4.

In general, a correlation analysis is required when analyzing the causal relationship between two variables. However, Spearman statistics can only reflect the correlation between the two variables but fails to prove the causal relationship between the two variables. On the contrary, if a causal relationship exists between the two variables, there must be a correlation between them. As can be seen from Table 4, the Sepearman statistic (The Spearman correlations among all variables have been showed in the table in the Appendix A.) is also significant while a causal relationship exists between independent variables and dependent variables.

Models 1 and 3 show that the non-agricultural income ratio has a significant positive impact on farmers' willingness to participate in fallow land while has no significant impact on the willingness to pay for the treatment of HMPF. The Spearman statistics also shows that there is a significant positive correlations between the non-agricultural income ratio and the farmers' willingness to participate in fallow land. Along with the large number of rural laborers going out to obtain non-agricultural income, the effective labor supply for agriculture is reduced. Further, the difficulty of mechanical substitution for labor in hilly areas means that agricultural production costs are high, and the benefits are low; thus, that the amount of abandoned farmland is gradually increasing. Farmers can obtain compensation for fallow land and thus, they are more willing to participate in fallow land treatment. Jiangxi Province and Hunan Province are both hilly regions with poor agricultural infrastructure and transportation conditions. Part-time employment among farmers is very common, especially for the many rural areas far from the urban centers, where family disposable income is low. With an increase in household disposable income from part-time work, farmers' first thoughts are to improve their lives, for example, by building or buying a new house or investing in their children's education and their awareness of farmland protection is poor. In addition, HMPF is invisible and long-term. Most farmers lack awareness of the impact of HMPF on their health or on the environment and are generally less willing to pay for the treatment of HMPF. However, the non-agricultural income ratio has a significant positive impact on farmers' willingness to participate in fallow farmland treatment and their willingness to pay for the treatment of heavy metal pollution of cultivated land after controlling for environmental awareness (see model 2 and model 4). This conclusion implies that the higher the household non-agricultural income is, the stronger farmers' willingness to govern HMPF will be if they understand the environmental role of HMPF. 
Table 4. Regression results for willingness to control HMPF.

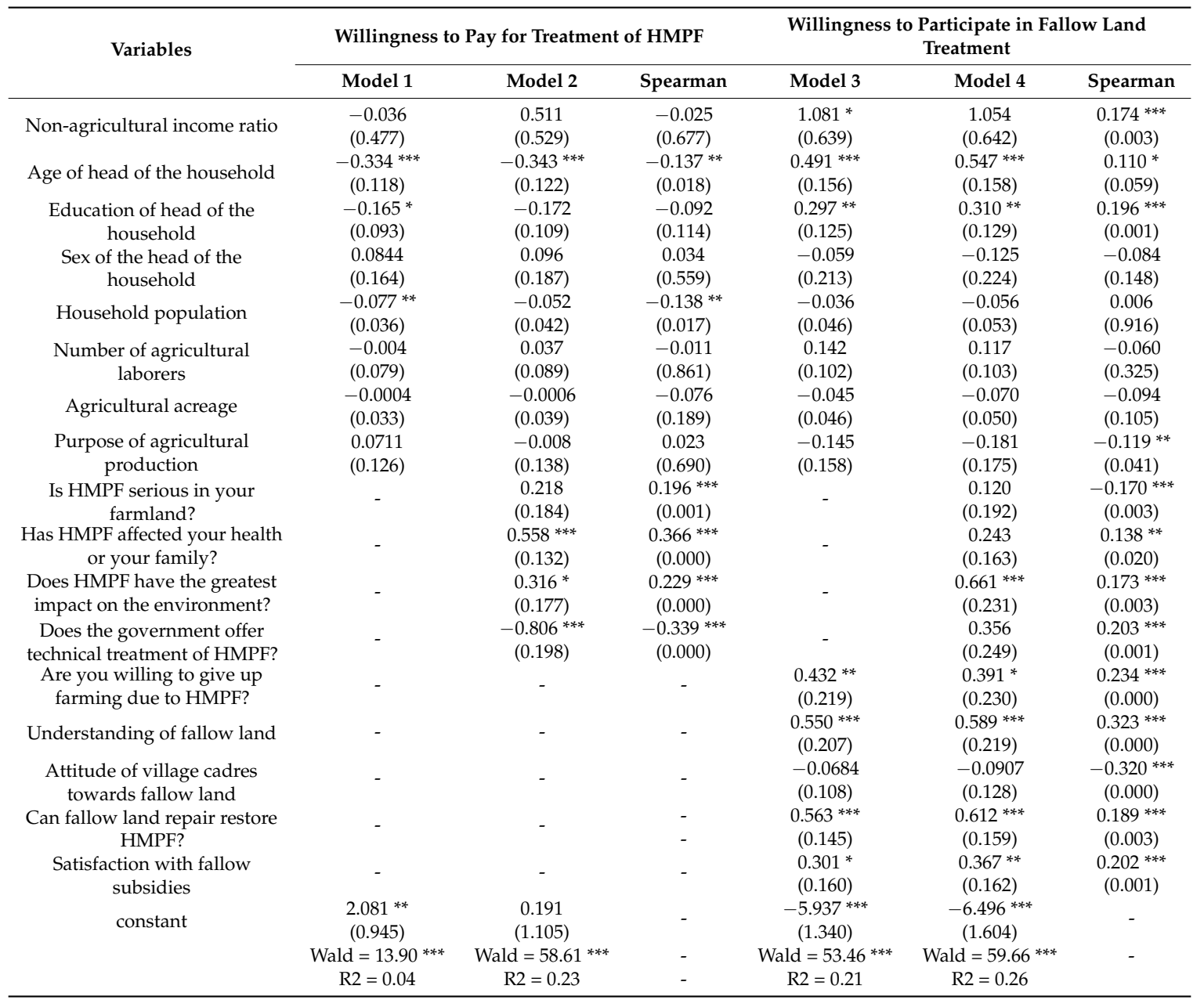

Note: (1) The values in parentheses in columns 2, 3, 5 and 6 are Standard Errors; (2) The values in parentheses in columns 4 and 7 are $p$-value; (3) ${ }^{* * * * * *}$ and ${ }^{*}$ represent $1 \%, 5 \%$ and $10 \%$ significance levels, respectively.

The next analysis is based on models 2 and 4 . In model 2, the influence of heavy metal pollution on health is significantly positive at the $1 \%$ level. That is, when farmers believe that HMPF has already affected their health or the health of their families, they are willing to pay for treatment. Most farmers in the sample areas believe that the government is mainly responsible for remediating HMPF. When farmers believe that the government should provide technical treatment for HMPF, their willingness to pay for treatment is significantly reduced. The impact of age is significantly negative at the $1 \%$ level. The older the farmer is, the less he or she is willing to pay for remediating HMPF. The aging agricultural labor force in hilly areas means lower awareness among farmers of the heavy metal pollution of cultivated land due to differences in knowledge levels and information acquisition ability. According to the results of model 4, when more farmers know about the benefits of fallow land, the stronger their willingness to participate in fallow land treatment will be. In general, if farmers believe that fallow land can restore HMPF, they are more satisfied with the fallow subsidy and more enthusiastic about and more willing to participate in fallow land treatment. Increasing farmers' cognitive understanding of fallow land is conducive to improving their subjective enthusiasm for participating in this treatment, reducing the cost and improving the efficiency of implementation. When farmers were asked if they "would give up farming because of HMPF," most said they would. That is, when the hazards of HMPF are clearly conveyed, farmers' enthusiasm for participating in fallow land treatment and abandoning farming increases. Farmers can obtain a subsidy for fallow land. The older the farmer is, the stronger the constraint of the agricultural labor supply and the more 
willing the farmer will be to leave land fallow. At the same time, the higher the education of head of the household is, the higher the probability he or she is willing to participate in fallow land treatment.

\section{Conclusions and Discussion}

HMPF has aroused widespread concern in recent years in China. In the context of increasing public demand for high-quality agricultural products and a better understanding of human health, this study analyzes the mechanism and degree through which non-agricultural employment and environmental awareness influence farmers' willingness to govern HMPF based on microdata from farmers in key Chinese provinces requiring heavy metal pollution prevention and control. The results show that most farmers in China believe that the government is mainly responsible for HMPF and they have a low willingness to govern HMPF. The increase in non-agricultural income of farmers in hilly areas does not significantly increase their willingness to control HMPF. Farmers generally believe that farmland is polluted by heavy metals and the awareness of environmental impacts of HMPF is gradually improving. Empirical research has found a close relationship between farmers' awareness of the environmental aspects of HMPF and their willingness to treat it. The higher their environmental awareness, the stronger their willingness to treat HMPF and the higher their enthusiasm for participating in fallow treatment.

Farmers are the ultimate behavioral subject of agricultural land use. For decades, the government in China has paid attention to the technical path and implementation effects of HMPF treatment while ignoring the role of farmers' environmental awareness in promoting the governance of HMPF. China is vigorously implementing actions to protect farmland quality and encouraging agricultural producers to adopt measures combining land use and land conservation to protect the quality of farmland. The government should focus more on introducing micro-incentive policies, strengthen positive publicity for the role of fallow land in the restoration of HMPF, improve farmers' environmental awareness of HMPF and encourage farmers to truly participate in the treatment of HMPF.

Great changes have taken place in agricultural production methods and the structure of farmers' livelihoods in China, given the continuous improvement and standardization of the farmland rights transfer market, resulting in a serious differentiation and prominent heterogeneity across farms and farmers. In this process, the government can provide relevant incentive measures, strengthen education and training on farmers related to environmentally friendly agricultural technologies and reduce heavy metal pollution caused by inputs to agricultural production at the source. Resource endowments, environmental awareness and the market environment are different for different farmers. To promote the treatment of HMPF, attention should be paid to the differences between farmers to ultimately reduce the cost and improve the efficiency of treatment.

Unreasonable agricultural production methods, such as the excessive application of chemical fertilizers and pesticides and the abuse of feed additives in farming, will cause HMPF. It is important to clarify the mechanisms responsible for HMPF during agricultural production and take targeted measures to control them. However, it is not enough to study it from the perspective of farmers' behavior or social science. Heavy metal pollution information provided by natural science has an important impact on farmers' perception and willingness to govern HMPF. Future research can be carried out with the interaction of social science and natural science and such work could determine key factors and provide theoretical support and a practical basis for treating HMPF.

Funding: This study was supported by the National Natural Science Foundation of China (No. 71803071); Natural Science Foundation in Jiangxi Province (No: 20181BAB211006); 11th batch of China Postdoctoral Science Foundation Special Funding (No. 2018T110655); Jiangxi Social Science Planning Youth Doctoral Fund Project in 2017 (No. 17BJ39) and Science and technology project of Jiangxi education department (No. GJJ180283).

Acknowledgments: The author gratefully appreciate the anonymous reviewers who made valuable and insightful comments on an earlier version of this manuscript.

Conflicts of Interest: H.L. had the original idea for the study and was responsible for data collecting and carried out the analyses. 


\section{Appendix A}

Table A1. The Spearman statistics among all variables.

\begin{tabular}{|c|c|c|c|c|c|c|c|c|c|c|c|c|c|c|c|c|c|c|c|}
\hline & Govern & Fallow & Ratio & Age & Edu & Sex & Population & Agrilabor & Area & Purpose & $\begin{array}{l}\text { Pollution } \\
\end{array}$ & Health & Environment & Technology & Understand & Abandonme & it Restore & Attitude & Satisfaction \\
\hline $\begin{array}{l}\text { Willingness to pay for } \\
\text { the treatment of HMPF } \\
\text { (govern) }\end{array}$ & 1.000 & & & & & & & & & & & & & & & & & & \\
\hline $\begin{array}{l}\text { Willingness to } \\
\text { participate in fallow } \\
\text { land treatment (fallow) }\end{array}$ & $-0.268^{* * * *}$ & 1.000 & & & & & & & & & & & & & & & & & \\
\hline $\begin{array}{l}\text { Non-agricultural } \\
\text { income ratio (ratio) }\end{array}$ & -0.025 & $0.174^{* * *}$ & 1.000 & & & & & & & & & & & & & & & & \\
\hline $\begin{array}{l}\text { Age of head of the } \\
\text { household (age) }\end{array}$ & -0.137 ** & $0.110^{*}$ & $-0.104 *$ & 1.000 & & & & & & & & & & & & & & & \\
\hline $\begin{array}{l}\text { Education of head of } \\
\text { the household (edu) }\end{array}$ & -0.092 & $0.196 * * *$ & 0.072 & $-0.225 * * *$ & 1.000 & & & & & & & & & & & & & & \\
\hline $\begin{array}{l}\text { Sex of the head of the } \\
\text { household (sex) }\end{array}$ & 0.034 & -0.084 & -0.025 & -0.035 & $-0.219 * * *$ & 1.000 & & & & & & & & & & & & & \\
\hline $\begin{array}{l}\text { Household population } \\
\text { (population) }\end{array}$ & -0.138 ** & 0.006 & 0.083 & -0.056 & 0.075 & 0.016 & 1.000 & & & & & & & & & & & & \\
\hline $\begin{array}{l}\text { Number of agricultural } \\
\text { laborers (agrilabor) }\end{array}$ & -0.011 & -0.060 & -0.099 & -0.074 & -0.091 & 0.053 & $0.149^{* *}$ & 1.000 & & & & & & & & & & & \\
\hline $\begin{array}{l}\text { Agricultural acreage } \\
\text { (area) }\end{array}$ & -0.076 & -0.094 & -0.008 & 0.066 & 0.057 & -0.048 & $0.242 * * *$ & 0.019 & 1.000 & & & & & & & & & & \\
\hline $\begin{array}{l}\text { Purpose of agricultural } \\
\text { production }\end{array}$ & 0.023 & -0.119 ** & $-0.194 * * *$ & $0.107 *$ & 0.026 & -0.013 & -0.059 & -0.052 & $0.156 * * *$ & 1.000 & & & & & & & & & \\
\hline $\begin{array}{l}\text { Is HMPF serious in your } \\
\text { farmland? (purrose)e } \\
\text { Has HMPF affected }\end{array}$ & $0.196 * * *$ & -0.170 *** & 0.002 & $-0.099 *$ & -0.031 & 0.104 * & -0.038 & $0.144^{* *}$ & 0.023 & -0.016 & 1.000 & & & & & & & & \\
\hline $\begin{array}{l}\text { your health or your } \\
\text { family? (pollution) } \\
\text { Does HMPF have the }\end{array}$ & $0.366 * * *$ & $0.138^{* *}$ & $-0.124^{* *}$ & -0.091 & -0.017 & 0.022 & $-0.174^{* * *}$ & -0.064 & 0.016 & 0.038 & $0.281^{* * *}$ & 1.000 & & & & & & & \\
\hline $\begin{array}{l}\text { greatest impact on the } \\
\text { environment? } \\
\text { (environment) }\end{array}$ & $0.229 * * *$ & $0.173 * * *$ & -0.054 & -0.059 & -0.025 & -0.074 & -0.093 & -0.035 & -0.058 & -0.079 & $0.182 * * *$ & $0.302 * * *$ & 1.000 & & & & & & \\
\hline $\begin{array}{l}\text { Does the government } \\
\text { offer technical treatment } \\
\text { of HMPF? (technology) }\end{array}$ & $-0.339 * * *$ & $0.203^{* * *}$ & $0.100^{*}$ & 0.011 & 0.090 & 0.032 & $0.097 *$ & 0.013 & 0.013 & -0.047 & -0.101 * & $-0.204 * * *$ & $-0.136 * *$ & 1.000 & & & & & \\
\hline $\begin{array}{l}\text { Understanding of } \\
\text { fallow land } \\
\text { (understand) }\end{array}$ & $0.256^{* * *}$ & $0.323^{* * *}$ & 0.078 & -0.031 & $0.230 * * *$ & -0.040 & -0.064 & 0.013 & -0.044 & -0.049 & -0.023 & $-0.136 * *$ & -0.084 & $0.248^{* * *}$ & 1.000 & & & & \\
\hline $\begin{array}{l}\text { Are you willing to give } \\
\text { up farming due to } \\
\text { HMPF? (abandonment) }\end{array}$ & -0.098 & $-0.234 * * *$ & 0.068 & -0.012 & $0.110^{*}$ & -0.081 & $-0.102^{*}$ & $-0.214^{* * * *}$ & 0.033 & 0.091 & $-0.104 *$ & -0.008 & 0.062 & 0.062 & 0.070 & 1.000 & & & \\
\hline $\begin{array}{l}\text { Can fallow land repair } \\
\text { restore HMPF? (restore) }\end{array}$ & $-0.112 *$ & $0.189 * * *$ & 0.034 & 0.01 & $0.180^{* * * *}$ & -0.042 & 0.027 & -0.013 & $-0.108 *$ & -0.042 & 0.001 & -0.098 & 0.024 & $0.222 * * *$ & $0.216 * * *$ & $0.108 *$ & 1.000 & & \\
\hline $\begin{array}{l}\text { Attitude of village } \\
\text { cadres towards } \\
\text { (attitude) }\end{array}$ & $-0.388^{* * *}$ & $-0.320^{* * * *}$ & 0.022 & 0.086 & $0.214^{* * *}$ & 0.002 & 0.059 & -0.043 & -0.015 & 0.040 & -0.243 **** & -0.325 **** & $-0.194 * * * *$ & 0.351 *** & $0.393 * * *$ & $0.164^{* *}$ & $0.365 * * *$ & 1.000 & \\
\hline $\begin{array}{l}\text { Satisfaction with fallow } \\
\text { subsidies (satisfaction) }\end{array}$ & $0.151^{* * * *}$ & $0.202 * * *$ & 0.141 ** & -0.083 & $0.113^{*}$ & -0.167 & -0.079 & -0.047 & 0.023 & -0.021 & $-0.110^{*}$ & -0.070 & -0.008 & 0.080 & 0.089 & 0.068 & $0.108 *$ & $0.133^{* *}$ & 1.000 \\
\hline
\end{tabular}

Note: ${ }^{* * *}, * *$ and $*$ represent $1 \%, 5 \%$ and $10 \%$ significance levels, respectively. 


\section{References}

1. Wang, Y.J.; Chen, N.C.; Liu, C.; Wang, X.X.; Zhou, D.M.; Wang, S.X.; Chen, H.M. Effective measures to prevent heavy metal pollution: Management and control methods based on loading capacity of soil: To international year of soil, IYS 2015. J. Agric. Environ. Sci. 2015, 34, 613-618.

2. Zhang, T.L. More comprehensive understanding and effective control of heavy metal pollution of cultivated soils in China. Soils 2015, 47, 435-439.

3. Li, Y.M.; Wang, X.; Hao, L.; Liu, Y.; Jiang, L.G. Heavy metal pollution control technology: Analysis of characteristics and influencing factors adopted by farmers. Chin. Rural Econ. 2017, 1, 58-67.

4. Wenzel, W.W.; Unterbrunner, R.; Sommer, P.; Sacco, P. Chelate-assisted phytoextraction using canola (Brassica napus L.) in outdoors pot and lysismeter experiments. Plant Soil 2003, 249, 83-96. [CrossRef]

5. Rajkumar, M.; Prasad, M.N.U.; Freitas, H.; Ae, N. Biotechnological applications of serpentine bacteria for phytoremediation of heavy metals. Crit. Rev. Biotechnol. 2009, 29, 120-130. [CrossRef] [PubMed]

6. Cai, Q.; Long, M.L.; Zhu, M. Food chain transfer of cadmium an lead to cattle in a lead-zinc smelter in Guizhou. China Environ. Pollut. 2009, 94, 3078-3082. [CrossRef] [PubMed]

7. Ministry of Ecology and Environment of the People's Republic of China. National Soil Pollution Investigation Bulletin; Ministry of Ecology and Environment of the People's Republic of China: Beijing, China, 2014.

8. Ministry of Natural Resources of the People's Republic of China. China Farmland Geochemical Survey Report; Ministry of Ecology and Environment of the People's Republic of China: Beijing, China, 2015.

9. Lohr, L.; Park, T.A. Utility-Consistent Discrete-Continuous Choices in Soil Conservation. Land Econ. 1995, 71, 474-490. [CrossRef]

10. Cooper, J.C.; Osborn, C.T. The Effect of Rental Rates on the Extension of Conservation Reserve Program Contracts. Am. J. Agric. Econ. 1998, 80, 184-194. [CrossRef]

11. Dorfman, J.H.; Barnett, B.J.; Bergstrom, J.C. Searching for farmland preservation markets: Evidence from the southeastern US. Land Use Policy 2009, 26, 121-129. [CrossRef]

12. Papatheodorou, E.M.; Kapagianni, P.; Georgila, E.D.; Monokrousos, N.; Stamou, G.P. Predictability of soil succession patterns under different agricultural land use practices: Continual conventional cultivation versus transformation to organic cultivation or fallow periods. Pedobiologia 2013, 56, 233-239. [CrossRef]

13. Xi, J.P. Report of the 19th National Congress of China; People's Publishing House: Beijing, China, 2017.

14. Lu, H.; Xie, H.L. Impact of changes in labor resources and transfers of land use rights on agricultural non-point source pollution in Jiangsu Province, China. J. Environ. Manag. 2018, 207, 134-140. [CrossRef]

15. Chen, M.Q. The Peasant Household Behavior and Social Responsibility of Cultivated Land Protection in China; Science Press: Beijing, China, 2018.

16. Dudas, M.J.; Pawluk, S. Heavy metals in cultivated soils and in cereal crops in Alberta. Can. J. Soil Sci. 1977, 57, 329-339. [CrossRef]

17. Nicholson, F.A.; Smith, S.R.; Alloway, B.J.; Carlton-Smith, C.; Chambers, B.J. An inventory of heavy metals inputs to agricultural soils in England and Wales. Sci. Total Environ. 2003, 311, 205-219. [CrossRef]

18. Ustyak, S.; Petrikova, V. Heavy metal pollution of soils and crops in Northern Bohemia. Appl. Geochem. 1996, 11,77-80. [CrossRef]

19. Blanco, G.; Sergio, F.; Frías, Ó.; Salinas, P.; Tanferna, A.; Hiraldo, F. Integrating population connectivity into pollution assessment: Overwintering mixing reveals flame retardant contamination in breeding areas in a migratory raptor. Environ. Res. 2018, 166, 553-561. [CrossRef] [PubMed]

20. Yang, Q.; Li, Z.; Lu, X.; Duan, Q.; Huang, L.; Bi, J. A review of soil heavy metal pollution from industrialand agricultural regions in China: Pollution and risk assessment. Sci. Total Environ. 2018, 642, 690-700. [CrossRef] [PubMed]

21. Baran, A.; Wieczorek, J.; Mazurek, R.; Krzysztof, U.; Klimkowiczpawlas, A. Potential ecological risk assessment and predicting zinc accumulation in soils. Environ. Geochem. Health 2018, 40, 435-450. [CrossRef] [PubMed]

22. Briki, M.; Ji, H.B.; Li, C.; Ding, H.J.; Gao, Y. Characterization, distribution, and risk assessment of heavy metals in agricultural soil and products around mining and smelting areas of Hezhang, China. Environ. Monit. Assess. 2015, 187, 1-21. [CrossRef]

23. Zhu, M.; Wei, A.N.; Liu, S.Y. Land system and land investment under family responsibility. Econ. Res. J. $1997,10,62-69$. 
24. Jacoby, H.; Li, G.; Rozelle, S. Hazards of expropriation: Tenure insecurity and investment in rural China. Am. Econ. Rev. 2002, 92, 1420-1447. [CrossRef]

25. Luo, B.; Li, J.B.; Huang, G.H.; Li, L.H. A simulation-based interval two-stage stochastic model for agricultural nonpoint source pollution control through land retirement. Sci. Total Environ. 2006, 361, 38-56. [CrossRef] [PubMed]

26. Chen, M.Q.; Feng, L.N.; Zhou, B.J. Empirical analysis of farmers' willingness to invest in farmland protection. China Rural Surv. 2008, 5, 23-29.

27. Zhu, Z.Q.; Liu, L.M.; Chen, Z.T. Land use change simulation and assessment of driving factors in the Loess hilly region-A case study as pengyang County. Environ. Monit. Assess. 2010, 164, 133-142. [CrossRef] [PubMed]

28. Yang, Z.H.; Wang, Y.P.; Tuersun, M.E.D. Farm households' input behavior of land conservation and its driving factors: From a perspective of farm household differentiation. China Popul. Resour. Environ. 2015, 25, 105-112.

29. Mesnard, A. Temporary migration and capital market imperfections. Oxf. Econ. Pap. 2004, 56, $242-262$. [CrossRef]

30. Zou, J.L.; Dong, Z.Y.; Wang, Y.B. The effects of labor migration on farmers' sustainable agricultural technology adoption decisions. Chin. Rural Econ. 2018, 8, 83-98.

31. Yang, Z.H.; Wang, Y.M. Research on cultivated land quality protection behavior of farmers in different generations-Based on a survey of 829 peasant households in Hubei and Henan provinces. J. Agric. Tech. Econ. 2015, 10, 48-56.

32. Chen, S.X. Economic significance of farmers' land plot vicissitudes-Based on the analysis of 1149 questionnaires. Qinghai Soc. Sci. 2012, 6, 80-85.

33. Zhao, H.F.; Zhang, F.R.; Jiang, G.H. Analysis of the trouble in cultivated land and prime farmland protection in Beijing suburbs based on peasents' household surveys. China Land Sci. 2008, 3, 28-33.

34. Tan, S.H. Do land characteristic affect farmers' soil fertility management. J. Integr. Agric. 2014, 13, $2546-2557$. [CrossRef]

35. Besley, T. Property Rights and Investment Incentives: Theory and evidence from Ghana. J. Political Econ. 1995, 103, 903-937. [CrossRef]

36. Feder, G.; Nishio, A. The benefits of land registration and titling: Economic and social perspectives. Land Use Policy 1998, 15, 25-43. [CrossRef]

37. Li, G.; Rozelle, S.; Brandt, L. Tenure, land rights and farmer investment incentives in China. Agric. Econ. 1998, 19, 63-71. [CrossRef]

38. Carter, M.R.; Yao, Y. Property Rights, Rental Markets and Land in China; Department of Agricultural and Applied Economics, Working Paper; University of Wisconsin: Madison, WI, USA, 1998.

39. Yao, Y. The System of Farmland in China: An analytical framework. Soc. Sci. China 2000, 2, 54-65.

40. Deininger, K.; Jin, S. Tenure security and land-related investment: Evidence from Ethiopia. Eur. Econ. Rev. 2006, 50, 1245-1277. [CrossRef]

41. Bi, J.Y.; Zhu, D.L.; Wang, X.F. Literature review on farm behaviors during the farmland preservation process based on domestic studies in China. China Land Sci. 2010, 24, 77-80.

42. Gao, L.L.; Ji, X.Q.; Hang, J.K. Analysis of the impact of the expectation of land right to use agricultural land on the long-term investment of agricultural land in China. Chin. Rural Econ. 2013, 11, 24-33.

43. Zou, J.M.; Liu, X.X.; Dai, W.; Luan, Y.N. Pollution assessment of heavy metal accumulation in the farmland soils of Beijing's suburbs. Environ. Sci. Pollut. Res. Int. 2018, 25, 27483-27492. [CrossRef]

44. Zhang, L.X.; Zhu, G.Y.; Ge, X.; Xu, G.; Guan, Y.T. Novel insights into heavy metal pollution of farmland based on reactive heavy metals (RHMs): Pollution characteristics, predictive models, and quantitative source apportionment. J. Hazard. Mater. 2018, 360, 32-42. [CrossRef]

45. Wu, W.; Wu, P.; Yang, F.; Sun, D.L.; Zhang, D.X.; Zhou, Y.K. Assessment of heavy metal pollution and human health risks in urban soils around an electronics manufacturing facility. Sci. Total Environ. 2018, 630, 53-61. [CrossRef]

46. Kamran, A.; Win, M.C. Heavy metal accumulation in soils and grains, and health risks associated with use of treated municipal wastewater in subsurface drip irrigation. Environ. Monit. Assess. 2015, 187, 410.

47. Fan, L.; Ye, W.L.; Chen, H.Y.; Lu, H.J.; Zhang, Y.H.; Li, D.X.; Tang, Z.Y.; Ma, Y.H. Review on contamination and remediation technology of heavy metal in agricultural soil. Ecol. Environ. Sci. 2013, 22, 1727-1736. 
48. Luo, Y.M.; Tu, C. Twenty Years of Research and Development on Soil Pollution and Remediation in China; Springer: Singapore, 2018.

49. Bermudez, M.A.; Jasanc, R.; Pla, R.; Pignata, M.L. Heavy metals and trace elements in atmospheric fall-out: Their relationship with topsoil and wheat element composition. J. Hazard. Mater. 2012, 213-214, 447-456. [CrossRef]

50. Wu, C.; Kang, H.B.; Zhang, X.Y.; Shao, H.B.; Chu, L.Y.; Ruan, C.J. A critical review on the bio-removal of hazardous heavy metals from contaminated soils: Issues, progress, eco-environmental concerns and opportunities. J. Hazard. Mater. 2010, 174, 1-8. [CrossRef]

51. An, J.; Gong, X.S.; Chen, H.W. Temporal and spatial characteristics and health risk assessments of heavy metal pollution in soils of Shenfu irrigation area. J. Agric. Environ. Sci. 2016, 35, 37-44.

52. Ren, S.X.; Li, E.L.; Deng, Q.Q.; He, H.S.; Li, S.J. Analysis of the impact of rural households' behaviors on heavy metal pollution of arable soil: Taking lankao county as an example. Sustainability 2018, 10, 4368. [CrossRef]

53. Aregay, F.A.; Minjuan, Z.; Tao, X. Knowledge, attitude and behavior of farmers in farmland conservation in china: An application of the structural equation model. J. Environ. Plan. Manag. 2018, 61, 1-23. [CrossRef]

54. Zhang, L.; Li, X.; Yu, J.; Yao, X. Toward cleaner production: What drives farmers to adopt eco-friendly agricultural production? J. Clean. Prod. 2018, 184, 550-558. [CrossRef]

55. Li, L.F.; Zeng, X.B.; Bai, L.Y. Accumulation of copper and zinc in soils under different agricultural and natural field. Acta Ecol. Sin. 2008, 28, 4372-4380.

56. Hammer, D.; Kayser, A.; Keller, C. Phytoextraction of $\mathrm{Cd}$ and $\mathrm{Zn}$ with salix viminalis in field trials. Soil Use Manag. 2003, 19, 187-192. [CrossRef]

57. Yu, Z.N.; Wu, C.F.; Shen, X.Q. Study of farmers' willingness for land fallow based on IAD extension decision model. J. Nat. Resour. 2017, 2, 198-209.

58. Xie, X.; Xie, H.L.; Shu, C.; Wu, Q.; Lu, H. Estimation of ecological compensation standards for fallow heavy metal-polluted farmland in China based on farmer willingness to accept. Sustainability 2017, 9, 1859. [CrossRef]

59. Ajzen, I. The theory of planed behavior. Organ. Behav. Hum. Decis. Process. 1991, 50, 179-211. [CrossRef]

60. Zhou, C.; Li, G.P. The influencing factors for willingness to pay of payment for watershed services: A case of the water receiving area of zhengzhou city of the middle route project of the south-north water transfer project. Econ. Geogr. 2015, 6, 38-46.

61. Chen, H.J.; Si, W.; Zhao, Q.R. The Scale Orientation and Targeting Deviation of Grain-soybean Rotation Subsidy: An Analysis Based on the Targeting Perspective of Ecological Compensation. Chin. Rural Econ. 2019, 1, 47-61.

62. Lu, H.; Xie, H.L.; He, Y.F.; Wu, Z.L.; Zhang, X.M. Assessing the impacts of land fragmentation and plot size on yields and costs: A translog production model and cost function approach. Agric. Syst. 2018, 161, 81-88. [CrossRef]

63. Statistic Bureau of Jiangxi. Jiangxi Statistical Yearbook; China Statistic Press: Beijing, China, 2017.

64. Statistic Bureau of Hunan. Hunan Statistical Yearbook; China Statistic Press: Beijing, China, 2017.

(C) 2019 by the author. Licensee MDPI, Basel, Switzerland. This article is an open access article distributed under the terms and conditions of the Creative Commons Attribution (CC BY) license (http://creativecommons.org/licenses/by/4.0/). 